\title{
Sustainable Social Work: An Environmental Justice Framework for Social Work Education
}

\author{
Samantha Teixeira \\ Boston College, samantha.teixeira@bc.edu \\ Amy Krings \\ Loyola University Chicago, akrings@luc.edu
}

Follow this and additional works at: https://ecommons.luc.edu/socialwork_facpubs

Part of the Social Work Commons

\section{Author Manuscript}

This is a pre-publication author manuscript of the final, published article.

\section{Recommended Citation}

Teixeira, Samantha and Krings, Amy. Sustainable Social Work: An Environmental Justice Framework for Social Work Education. Social Work Education, 34, 5: 513-527, 2015. Retrieved from Loyola eCommons, Social Work: School of Social Work Faculty Publications and Other Works, http://dx.doi.org/10.1080/ 02615479.2015 .1063601

This Article is brought to you for free and open access by the Faculty Publications and Other Works by Department at Loyola eCommons. It has been accepted for inclusion in Social Work: School of Social Work Faculty Publications and Other Works by an authorized administrator of Loyola eCommons. For more information, please contact ecommons@luc.edu. c) (†) $\Theta$

This work is licensed under a Creative Commons Attribution-Noncommercial-No Derivative Works 3.0 License. Author Posting @ Routledge 2015. 
Sustainable Social Work: An Environmental Justice Framework for Social Work Education

\section{Samantha Teixeira \& Amy Krings}

Environmental degradation is not experienced by all populations equally; hazardous and toxic waste sites, resource contamination (e.g., exposure to pesticides), air pollution, and numerous other forms of environmental degradation disproportionately affect low income and minority communities. The communities most affected by environmental injustices are often the same communities where social workers are entrenched in service provision at the individual, family, and community level. In this article, we use a global social work paradigm to describe practical ways in which environmental justice content can be infused in the training and education of social workers across contexts in order to prepare professionals with the skills to respond to everincreasing global environmental degradation. We discuss ways for social work educators to integrate and frame environmental concerns and their consequences for vulnerable populations using existing social work models and perspectives to improve the social work profession's ability to respond to environmental injustices. There are significant social work implications; social workers need to adapt and respond to contexts that shape our practice, including environmental concerns that impact the vulnerable and oppressed populations that we serve.

The social work profession utilizes the 'person in the environment' (PIE) perspective to understand individual and community level problems. However, the profession has largely defined this environmental perspective solely through the lens of the social environment, despite a great deal of knowledge that the built and natural environments are related to health and wellbeing (Coates \& Gray, 2012; Kemp, 2011; McKinnon, 2008; Miller, Hayward, \& Shaw, 2012; Rogge, 1993; Zapf, 2009).

There is a growing push for social workers to better understand the interdependence between people and their socio-cultural, economic, and physical environments (Dominelli, 2012; Hoff \& Rogge, 1996; Kelley, 2011). These environmentally focused social workers have highlighted the profession's role in simultaneously promoting environmental and social justice.

In this article, we describe practical ways in which social work educators can infuse environmental justice principles and interventions into traditional social work training; recognizing the intersectionality of social and environmental inequality. We first provide a brief background to describe global environmental degradation, with an emphasis on how the distribution of environmental hazards disproportionately burdens the poor and racial minorities. Next, we present an original framework that integrates global social work standards with environmental justice principles. This framework, based on global standards for social work set forth by The International Federation of Social Workers (IFSW) and the International Association of Schools of Social Work (IASSW), includes four practice guideposts with illustrative case examples that can be used by educators to train social work students and practitioners. We conclude with a description of social work implications, in particular, the unique opportunity for social work professionals to bring our skills and perspectives to bear on 
environmental justice issues. Finally, we recommend that social workers adapt and respond to contexts that shape our practice, integrating environmental concerns that impact the vulnerable and oppressed populations that we serve.

\section{Background}

The issue of environmental degradation has seen increased global recognition among social service and health professionals after being highlighted as one of the United Nations' (UN) Millennium Development Goals (United Nations, 2000). As part of this goal, the UN aims to support sustainable development policies and programs that stem the degradation of environmental resources including safe drinking water, firewood, and basic sanitation.

Research suggests that environmental degradation does not impact all populations equally; low income and minority communities are more likely to be exposed to air, land, and water contamination, and are least equipped to mitigate the resulting harm to human health and the natural environment (Brown, 1995; Burger \& Gochfeld, 2011; Mohai, Pellow, \& Roberts, 2009). In part, this is why low-income racial minorities are more likely to live and work near toxic and hazardous facilities such as interstates, garbage facilities, and wastewater treatment plants (Austin \& Schill, 1991; Mohai \& Bryant, 1992). These types of noxious facilities - known as 'locally undesirable land uses' or 'LULUs' - appear necessary to the broader society, but create environmental burdens and ultimately health impacts among host community residents.

These land use decisions culminate in a phenomenon known as 'environmental racism' because communities with higher percentages of racial minorities are more likely to be exposed to pollution and toxic waste, bear the brunt of the mental and physical health hazards resulting from environmental degradation, and experience unique vulnerabilities (e.g., powerlessness, oppression) that leave them exposed to environmental hazards (Chavis, 1994; Holifield, 2001; Mohai \& Bryant, 1992; Mohai et al., 2009). Because the health of host community residents is sacrificed while the broader society benefits, these places have described as 'sacrifice zones' (Lerner, 2010). The manner in which we distribute environmental benefits and sacrifice zones has serious implications for people's physical and social well-being. Many global conflicts can be traced to issues of access to land, water, oil, and other natural resources.

Environmental sustainability and environmental justice are two principles that can be applied to begin addressing these disparities. Sustainability is broadly defined as using natural resources necessary for human survival responsibly so that they will remain available for future generations (EPA, 2014). Environmental justice interventions aim to promote a safe, clean environment and meaningfully involve all people in policy and development decisions that affect their environment (EPA, 2014; Mohai \& Bryant, 1992; Rogge, 1993). Social workers, traditionally concerned with the promotion of human rights and social justice, are primed to be strong partners in environmental justice movements.

Addressing environmental degradation is not a new area for social work but a return to the roots of the profession - a focus that was marginalized as the scope of social work education and 
practice was narrowed following the professionalization of Flexner's medical model in the early twentieth century. In her call to action urging social workers to return to their environmental roots, Kemp (2011) argued that, 'Although social work is optimally positioned to respond to the human implications of environmental change and stress, the profession largely lacks a presence in environmental practice, research, and policy-making' (p. 1198). The communities most affected by environmental injustices are the same communities where social workers are entrenched in service provision at the individual, family, and community level (McKinnon, 2008). In this article, we join a vocal group of social work educators (Coates \& Gray, 2012; Dominelli, 2012; Kemp, 2011; Rogge, 1993) in urging social workers to consider a paradigm shift that embraces the role social workers can play in environmental and social justice advocacy.

Global Standards for Social Work Education and Practice: A Framework to Apply Environmental Justice Content

The International Federation of Social Workers (IFSW) and the International Association of Schools of Social Work (IASSW) jointly developed global standards for social work including an internationally accepted definition of social work and educational practice standards. The creators of the document set forth to identify universal aspects of social work that could guide the training and education of social workers across the globe (IFSW, 2012). They argued that although local context is important in social work training, the core purposes and universal paradigm that guide social workers cut across national boundaries.

Utilizing the paradigm as laid out by the IASSW and the IFSW, this article offers practical suggestions for social work educators to weave environmental justice content into traditional social work training 1 ; integrating environmental concerns and their consequences for vulnerable populations (including individuals, families, and communities across the globe).

The key points of the paradigm will be used as a guide to infuse environmental justice content throughout global social work training and education. The primary paradigmatic guideposts ${ }^{2}$ we use are:

- $\quad$ Recognition of the dignity and worth of all human beings, respect and appreciation for diversity and the assumption, identification, and recognition of strengths and potential of all human beings;
- Recognition of the interconnectedness among micro, mezzo, and macro systems;

economic

The importance of advocacy and changes in socio-structural, political, and conditions that disempower, marginalize, and exclude people; 
- $\quad$ Focus on capacity-building and empowerment of individuals, families, groups, organizations and communities through a human-centered developmental approach.

Though the authors are from the USA and their experiences reflect US-based

training and practice, this article is relevant to a global social work education audience because it focuses on skills, values, and examples of interventions that can be taught in relation to each of the global paradigmatic guideposts outlined above. We focus on core social work values and their application to environmental justice relevant skills and competencies and provide case studies for each guidepost that can be used by social work educators to illustrate how these skills and values can be applied in an international context.

Guidepost 1: Recognition of Dignity and Worth, Diversity, and Strengths Perspective

Social workers who are attentive to social justice examine their interventions through principles of equality and fairness. They commit to respecting the dignity and worth of the individuals with whom they work, regardless of race, social status, or access to power. This lens - utilized to promote social justice - also provides a strong framework for delivering environmental justice content in social work education (Pillai \& Gupta, 2012).

Values and Perspectives

Global environmental issues, such as climate change, cut across political, economic, cultural, and social boundaries. Though toxic risk and exposure to pollution and contamination are global phenomena, they disproportionately affect members of low-income and minority communities (Mohai et al., 2009; Morello-Frosch \& Jesdale, 2006).

As social work educators, we train our students to identify the root causes of social problems, rather than to 'blame the victim'. This approach, unique to social work, can be applied to issues including environmental degradation. Instead of blaming the poor for their problems, we can emphasize the underlying social, political, and economic systems that produce environmental degradation and the role of social workers in intervention. For example, limited financial options constrain housing options, requiring some poor families to live within hazardous environments (Austin \& Schill, 1991). In addition, because it is understood that new hazardous developments will be opposed by any host community, corporate leaders are incentivized to build within politically marginalized areas.

In their recommendations to the Council on Social Work Education (CSWE) Global Commission, Pillai and Gupta (2012) stated that social workers should focus on both social inequality and poverty as the underlying causes of ecological degradation. If we train social work professionals to understand environmental degradation as a problem that intersects with poverty and other problems we commonly address as social workers, we can train them to use our existing skillsets and models of intervention to simultaneously address environmental 
degradation. As social workers, when we respect the right of all people to a safe, clean environment, we also respect their right to self-determination. The poor are not typically afforded a voice in determining land use and thus may become the default for toxic site location, illegal dumping, or other environmental degradation (Bullard, Mohai, Saha, \& Wright, 2008). Social workers have a role to play in ensuring that these traditionally disenfranchised populations have a voice in decisions that affect their individual and environmental well-being.

Skills

One of the key roles of social workers around the globe is to recognize strengths in diverse and oppressed groups and harness their potential for action and empowerment. As part of our training, we prepare students to do this work by developing skills including the ability to demonstrate self-awareness of personal bias (IFSW, 2012; NASW, 2008). Though it is common to work with students to develop awareness of biases such as racial or socioeconomic prejudice, we can expand this practice to the built and natural environment (e.g., biases against working in blighted neighborhoods in legacy cities or slums in rapidly urbanizing cities in the developing world).

Another skill common to social workers worldwide is the ability to recognize and create awareness of the intersections of forms of oppression in shaping life experiences (IFSW, 2012). In order to infuse environmental justice content into this skill area, instructors can work with students to examine the intersection of poverty and environmental health disparities, with special attention to the role that power and privilege play in both poverty and health disparities. Social work educators may use successful environmental justice movements to showcase the ability of marginalized populations to organize and advocate for safe conditions in their neighborhoods and communities.

\section{Case Study Example}

The Toxic Free Neighborhoods project, which took place in the Old Town industrial district of San Diego, CA, USA, exemplifies the values and skills inherent in Guidepost 1. Many of the environmental justice campaigns throughout the USA originated with the goal of reducing asthma and other respiratory illnesses associated with exposure to pollution (Sze, 2007). In the Toxic Free Neighborhoods project, for example, after a team of researchers documented the linkage between the neighborhood's high rate of asthma and concentration of manufacturing facilities, they recruited and trained lay health workers or promotoras de salud who were women from the neighborhood with children impacted by asthma. The promotoras then interviewed residents about their experiences with pollution, as well as asking them to describe what it is like to live with asthma (Minkler, Garcia, Williams, LoPresti, \& Lilly, 2010).

The researchers and promotoras then created a public awareness campaign based on their 'statistics and stories' that ultimately catalyzed policy makers to address the pollution. This intervention built upon the strengths and lived experiences of the promotoras, particularly their dual roles as mothers and co-researchers. Because the research team respected residents' dignity 
by amplifying their voices, the mothers whose families had experienced the problem first-hand were afforded a voice in land use decisions related to the health of their children. The campaign resulted in the incorporation of environmental justice principles within San Diego's planning processes as well as a plan to relocate harmful, polluting facilities outside of the neighborhood.

Guidepost 2: Recognition of the interconnectedness among micro, mezzo, and macro systems

Social work's recognition of the multi-systemic nature of social problems makes us unique among helping professions. Although we are leaders in the use of the ecological systems perspective to intervene across multiple systems levels, we remain focused largely on social ecology, minimalizing or even ignoring the importance of natural ecological systems (Coates \& Gray, 2012; Zapf, 2009). The second paradigmatic guidepost is an area where we can infuse environmental justice content by utilizing our existing systems perspective and person in environment approach to guide students to an understanding of the complex interplay between humans and the environment.

Values and perspectives

In our use of the person in environment and ecological perspectives, we often artificially separate the social and natural environment, when in all actuality the built, natural, and social environments are intertwined (McKinnon, 2008). As social work educators, we can use our existing ecological framework to guide students to understand the natural and built environment as part of the macro context of practice. Our multi-systemic perspective and ability to work within and across systems is an ideal jumping off point to teach social workers to recognize that environmental injustice is a globalized issue with individual, local, and global implications (Mary, 2008). Further, we can help students recognize the interconnectedness of the natural and social environments and their impact on the well-being of the individuals, groups, and communities with whom we work.

Skills

At the heart of the social work profession is our skill at crossing systemic boundaries to act as advocates and organizers while also playing a professional therapeutic role for individuals and communities (Dominelli, 2012). Social workers can bring this practice skill to bear to address issues related to environmental degradation. At the micro level, social workers can apply the person in environment perspective to their individual therapeutic interventions, with specific attention to the role of the natural and built environment in individual outcomes. At the mezzo level, social workers are well positioned to be the conduit for interdisciplinary approaches to enact systems change; for example, linking urban planning professionals and policy makers to organizations providing human services. At the macro level, social workers are skilled at engaging in consciousness raising and social action interventions to bring to light environmental racism and involve community members in efforts to address environmental inequalities. As social work educators, we can help students learn interventions at multiple systems levels and understand the interconnectedness of these approaches, using evidence to inform their practice. 


\section{Case Study example}

We illustrate Guidepost 2 in action through this case study of the Movement for the Survival of the Ogoni People (MOSOP), a classic example of a grassroots advocacy effort that addressed environmental and social problems using a multi-systemic intervention. This effort, led by affected residents rather than social service providers, can be used to illustrate how social workers can learn from and partner with local movements that promote social work values. The Ogoni people are a Nigerian minority ethnic group residing in Ogoniland, an area of Nigeria rich with natural resources, including crude oil reserves (Adeola, 2000). The Ogoni people face multiple levels of oppression and experience economic deprivation, economic and political discrimination, and environmental degradation due to their location amidst oil fields and other sought-after natural resources. While the natural resources located in Ogoniland create profit for multinational corporations, the Ogoni people bear the brunt of the hazards produced while extracting these natural resources, without economic benefits (Adeola, 2000). The environment of Ogoniland has been severely devastated by hazardous waste dumping and toxic emissions, further marginalizing the Ogoni people.

Led by Kenule Saro-Wiwa, the MOSOP was formed in 1990 to promote consciousness raising among the Ogoni people, mobilize a collective effort to combat disadvantage, and to use nonviolent organizing strategies to address oppression (Adeola, 2000). They held mass demonstrations and lobbied their elected representatives to address the pollution and the violent treatment by the military resulting from their resistance. Over time, the group gained international attention through their advocacy and simultaneously promoted human rights and environmental justice, presenting before the United Nations Commission on Human Rights in 1992. Social work professionals can learn from the Ogoni people and their use of advocacy to hold corporations accountable for the ways that they impact the health and well-being of people who are poor and yet live in resource-rich places.

Guidepost 3: The importance of advocacy and changes in socio-structural, political and economic conditions that disempower, marginalise and exclude people

The profession of social work is committed to advocating for changes in conditions that disempower and marginalize individuals and communities. This integral tenet of social work can be used to conceptualize environmental injustice in relation to systems of oppression that we traditionally train students to recognize and intervene in such as poverty, political disenfranchisement, and segregation.

Values and perspectives

Social workers engage with many clients and communities that suffer from environmental health impacts. Some help to mitigate harm by caring for individuals in need. However, the IFSW (2012) stated that it is also necessary to advocate for changes in the conditions that give rise to environmental injustice - those that disempower, marginalize, and exclude people. We already teach students the concepts of empowerment and show them how to use the strengths perspective 
in their work, often with a focus on individual client strengths. We can expand the way we integrate these values and perspectives into our teaching by utilizing macro, environmental justice-related examples that draw upon client and community strengths to catalyze community action.

Skills

To accomplish these goals, social work educators train future social workers to recognize and articulate the ways in which political, economic, and social structures oppress some identity groups while enhancing the power and privilege of others. In many programs, this type of analysis is already offered. However, there may be new opportunities to teach these practical skills by offering examples of political decisions and 'non-decisions' (Bachrach \& Baratz, 1962) that are made (or ignored) relating to the use of land and water (Auyero \& Swistun, 2009; Crenson, 1971; Gaventa, 1980). For example, educators can ground critical analysis within local decisions about transportation, water distribution, housing, waste disposal, energy consumption, and pollution.

Social work educators commonly teach methods including consciousness-raising and social action. In order to use these common traditions to integrate environmental justice content, educators might lead trainings, discussion groups, or even public awareness campaigns to call attention to the disproportionate placement of locally undesirable land uses in poor areas and their impact on health. Students might analyze questions like, 'where are all the trash disposal centers located within the state?' and 'what are the demographics in these neighborhoods?' to better draw the connection between political disenfranchisement, marginalization, and environmental injustice.

Beyond analysis and consciousness-raising, skills relating to mobilization, collective action, and advocacy are necessary. Social workers already act as advocates, community organizers, lobbyists, policy makers, and researchers. We can expand upon these roles to promote environmental justice. For example, Lavelle and Coyle (1992) documented that not only are toxic facilities systematically placed within low-income communities of color in the USA, but they are also fined less often by the Environmental Protection Agency and, when they are fined, receive less serious consequences than similar factories in comparably affluent or white areas. Globally, the issue is even more stark; $95 \%$ of individuals affected by pollution-related health problems reside in developing countries and for them, pollution management is an urgent issue (World Bank, 2015). Social workers can assist within existing environmental justice campaigns or mobilize new ones designed to prevent the location of toxic facilities in poor areas while calling for increased accountability. This builds upon our skills relating to recruitment, coalitionbuilding, and lobbying, and can be grounded within an environmental justice perspective.

Case Study Example

Guidepost 3 calls for changes in socio-structural, political, and economic conditions that disempower, marginalise, and exclude people. Our first and second case studies exemplified 
policy reforms shaped by communities that host locally undesirable land uses (LULUs) — such as factories and oil refineries. In many of the most marginalized communities, environmental justice campaigns have yet to arise. These types of communities provide examples that can be used by social work educators to help students think critically about how to mobilize campaigns that address broader political and economic conditions that may not be easily addressed by fragmented, politically disenfranchised communities. This case study describes political and economic conditions that have led to the disenfranchisement of the Roma people in Europe and how they have led to stark environmental health disparities.

The Roma people are one of the largest minority groups in the European Union (EU); an estimated 10-12 million Roma live across Europe (European Commission, 2015). They have been discriminated against by majority populations for more than 1000 years, first as slaves in Hungary and Romania, then systematically targeted for extermination by Nazis, and today they remain the targets of discriminatory housing and economic policies (Fox, 2001). Due to systematic exclusion from the formal workforce, the Roma are often forced into occupations that involve exposure to highly toxic hazards including coal and uranium mining and scrap metal processing (Antypas et al., 2007; Harper, Steger, \& Filcª'k, 2009).

This political, racial, and economic discrimination also results in geographic marginalization; the Roma are often relocated from towns with strict housing ordinances and placed in highly polluted, undesirable geographic areas. This systemic discrimination means that the Roma are more likely to live in areas proximate to waste treatment facilities, industrial sites, and high traffic areas (Antypas et al., 2007). Research suggests that environmental health disparities contribute to a 10-15 year reduced life expectancy among Roma compared to their non-Roma counterparts (Antypas et al., 2007; Parry et al., 2004). Though Romani activists and Hungarians have been pushing to organize the Roma community to address discriminatory policies that lead to environmental injustices, wide health disparities still exist (Harper et al., 2009). A promising policy framework for environmental health exists in the EU but there is still need for more concrete efforts to promote environmental justice. This is a potential political advocacy opportunity for social workers and environmentalists who may be able to work with Romani activists to address the complex intersection of racial discrimination, exclusion, and poor environmental health.

Guidepost 4: Focus on Capacity-building and Empowerment of Individuals, Families, Groups, Organizations and Communities through a Human-centered Developmental Approach

Social workers view empowerment as both a process and an outcome. We promote interventions and approaches that simultaneously build individual and community capacity, which can allow us to leverage assets across systems. This human-centered and community-centered approach promotes participatory decision making, particularly with regard to environmental issues.

Values and Perspectives 
Though the empowerment perspective has roots in numerous academic disciplines, it is among the most commonly used perspectives in social work practice (Gutierrez, Parsons, \& Cox, 1998). Despite its fundamental role in social work research and practice, empowerment is often an ambiguous concept. For example, participation in decision-making processes can be an empowering experience when a participant's input is valued and implemented. However, participation can be tokenizing or even manipulative when participants are not taken seriously and do not have influence over the outcome (Arnstein, 1969). At its most basic form, empowerment requires access to information. In the case of environmental injustices, social workers may need to take highly technical and scientific information and translate it into a form that ordinary citizens can understand. Furthermore, they may need to utilize the empowerment perspective to push for more participatory governance, which requires the understanding of various proposals under consideration and the viewpoints all those affected - including government officials, developers, and residents.

\section{Skills}

Social workers have historically used empowerment interventions to address numerous macrolevel social issues, including environmental injustices. For example, Jane Addams and Hull House staff engaged residents to intervene in neighborhood quality of life issues (e.g., waste disposal, workplace safety) through community organizing, consciousness raising, and other essential social work skills related to empowerment (Kemp, 2011). More recently, global health professionals, including social workers, have utilized a variety of innovative approaches to empower historically oppressed populations to address environmental issues. Social workers can utilize a variety of empowering research and engagement approaches including but not limited to Community Based Participatory Research (CBPR) (Minkler \& Wallerstein, 2011; Wallerstein \& Duran, 2008), Participatory Action Research (PAR) (Whyte, 1991), community organizing, and consensus building (Fisher \& Kling, 1993; Fisher \& Shragge, 2000). Social work researchers and practitioners alike can perform this role using long-established social work skills such as engaging, assessing, and intervening within at-risk communities. They can co-produce knowledge about environmental issues and their impacts with local stakeholders, and they can disseminate research data so that it can be used to further the community's visions for change.

\section{Case Study Example}

Empowerment is perhaps the most widely used intervention tool in the field of social work (Pillai \& Gupta, 2012). Its core philosophy is that people should have influence over the decisions that impact their lives. A well-known example of empowerment in the context of environmental justice is the Dudley Street Neighborhood Initiative in which a Boston community was identified by city officials and developers as a site for urban renewal, to replace affordable, but blighted housing units with market-rate housing (Medoff, 1994). While the residents agreed with the need to address illegal dumping and blight within their community, they were concerned because they were both left out of the planning process and feared that they-like other communities that were bulldozed in the name of urban renewal - would be either forcefully relocated or priced out through gentrification. 
In response, the residents of Dudley Street organized using an empowerment approach. They secured funding to hire local organizers to craft environmental justice campaigns, including one titled 'Don't Dump on Us' to shut down illegal dumping of garbage and hazardous materials. In addition, they development their own resident-driven planning process to create new housing that was safe and affordable. They maintained their new development and surrounding environment by organizing a youth council, painting murals, and promoting organized activities in public park spaces (Medoff, 1994). Their use of empowering, participatory strategies can serve as an example for training social workers to critique top-down planning that culminates in environmental disadvantage and, more importantly, to offer alternatives.

Implications for Social Work Education

The framework described in this article has important implications for educating future generations of social workers. We argue that social work not only has the skills and tools to address environmental problems, but, as a discipline our theories and perspectives make us uniquely qualified to work at the intersection of social and environmental justice. Unfortunately, to our knowledge, few social work programs explicitly incorporate environmental justice content into their courses, so social workers may not perceive environmental justice as an issue within the profession's purview (Kemp, 2011).

We need to prepare our students to address this global issue. Social workers have many tools that can help mitigate environmental risk among vulnerable populations. We recognize the importance of self-determination and have the skills to bring marginalized communities to the table in order to change decision-making processes that in the past, have disproportionately harmed already oppressed groups. As the social work profession grapples with the implications of globalization, we will need to better integrate environmental content into our classrooms, our field training, and our daily practice. The framework presented in this article can be used as a first step that will expose students to environmental justice through our existing social work paradigms. Through this exposure, social workers may more readily take their place as interdisciplinary players in the global response to environmental degradation.

Conclusion

Social workers are charged with adapting and responding to contexts that shape our practice (CSWE, 2008). Environmental degradation is a pressing, global problem and is concentrated in oppressed populations and oppressed geographic regions. This matters to our clients. The human impacts of environmental challenges fall most heavily on those to whom social workers are most accountable (Hoff \& Rogge, 1996; Kemp, 2011).

In this article, we described ways in which social work educators can infuse environmental justice content in social work education and training while using existing social work perspectives, skills, and interventions. We urge social work educators to tackle the issue of environmental justice by first, educating future social workers to view environmental justice as a core component of social justice, and second, to bring social work values and skills to 
partnerships addressing environmental degradation. We are not the first to urge the profession to expand the ecological model beyond the social environment to a more holistic view of the social, natural, and built environment as spheres for social work practice; in fact, it is deep within the historical roots of our profession (Dominelli, 2012; Hoff \& Rogge, 1996; Kemp, 2011; Pillai \& Gupta, 2012; Rogge, 1993). Social work education is poised to use our existing practice models to train students to understand that environmental justice is social justice.

Notes

[1] Because the framework focuses on the core purposes and universal paradigm that guides social work education, this framework is applicable for undergraduate and graduate education.

[2] The original document had 8 epistemological paradigms that we consolidate into 4 environmental justice relevant guideposts. 


\section{References}

Adeola, F. O. (2000). Cross-national environmental injustice and human rights issues: A review of evidence in the developing world. American Behavioral Scientist, 43, 686-706. doi:10.1177/ 00027640021955496

Antypas, A., Borthwick, F., Cahn, C., Filcak, R., Harper, K., \& Steger, T. (2007). Making the case for environmental justice in Central and Eastern Europe. Retrieved from http:/www.envhealth. org/IMG/pdf/ceu_teljes_pdf.pdf

Arnstein, S. R. (1969). A ladder of citizen participation. Journal of the American Institute of Planners, 35, 216-224. doi:10.1080/01944366908977225

Austin, R., \& Schill, M. (1991). Black, brown, poor \& poisoned: Minority grassroots environmentalism and the quest for eco-justice. Kansas Journal of Law and Public Policy, 1, 69.

Auyero, J., \& Swistun, D. A. (2009). Flammable: Environmental suffering in an Argentine shantytown.

New York, NY: Oxford University Press.

Bachrach, P., \& Baratz, M. S. (1962). Two faces of power. American Political Science Review, 56, 947-952. doi:10.2307/1952796

Brown, P. (1995). Race, class, and environmental health: A review and systematization of the literature. Environmental Research, 69, 15-30. doi:http://dx.doi.org/10.1006/enrs.1995.1021

Bullard, R. D., Mohai, P., Saha, R., \& Wright, B. (2008). Toxic wastes and race at twenty: Why race still matters after all of these years. Environmental Law (Northwestern School of Law), 38, 371.

Burger, J., \& Gochfeld, M. (2011). Conceptual environmental justice model for evaluating chemical pathways of exposure in low-income, minority, native American, and other unique exposure populations. American Journal of Public Health, 101, S64-S73.

doi:10.2105/AJPH.2010.300077

Chavis, B. F. (1994). Preface. In R. D. Bullard (Ed.), Unequal protection: Environmental justice and communities of color (pp. xi-xii). San Francisco, CA: Sierra Club Books.

Coates, J., \& Gray, M. (2012). The environment and social work: An overview and introduction. International Journal of Social Welfare, 21, 230-238. doi:10.1111/j.1468-2397.2011.00851.x

Crenson, M. A. (1971). The un-politics of air pollution: A study of non-decision-making in the cities. Baltimore, MD: Johns Hopkins Press. 
CSWE. (2008). Educational Policy and Accreditation Standards (EPAS): Council on Social Work Education. Retrieved from http://www.cswe.org/File.aspx?id=13780

Dominelli, L. (2012). Green social work: From environmental crises to environmental justice. Malden, MA: Polity.

EPA. (2014). What is sustainability? Retrieved from

http://www.epa.gov/sustainability/basicinfo.htm

European Commission. (2015). EU and Roma. Retrieved from http://ec.europa.eu/justice/discrimination/roma/index_en.htm

Fisher, R., \& Kling, J. (Eds.). (1993). Mobilizing the community: Local politics in a global era. Newbury Park, CA: Sage.

Fisher, R., \& Shragge, E. (2000). Challenging community organizing: Facing the 21st Century. Journal of Community Practice, 8(3), 1-19. doi:10.1300/J125v08n03_01

Fox, J. (2001). Patterns of discrimination, grievances and political activity among Europe's Roma: A cross-sectional analysis. Journal of Ethnopolitics and Minority Issues in Europe, 2, 125 .

Gaventa, J. (1980). Power and powerlessness: Quiescence and rebellion in an Appalachian Valley (vol. 36). Urbana, IL: University of Illinois Press.

Gutierrez, L. M., Parsons, R. J., \& Cox, E. O. (1998). Empowerment in social work practice. A sourcebook. Pacific Grove, CA: Brooks-Cole.

Harper, K., Steger, T., \& Filc`a'k k, R. (2009). Environmental justice and Roma communities in Central and Eastern Europe. Environmental Policy and Governance, 19, 251-268.

doi:10.1002/eet.511

Hoff, M. D., \& Rogge, M. E. (1996). Everything that rises must converge: Developing a social work response to environmental injustice. Journal of Progressive Human Services, 7, 41-57.

Holifield, R. (2001). Defining environmental justice and environmental racism. Urban Geography, 22, 78-90. doi:10.2747/0272-3638.22.1.78

IFSW. (2012). Global standards for the education and training of the social work profession. Retrieved from http://ifsw.org/policies/global-standards/.

Kelley, M. (2011). On the social construction of place: Using participatory methods and digital tools to reconceive distressed urban neighborhoods. In S. E. Sutton \& S. P. Kemp (Eds.), The paradox of urban space: Inequality and transformation in marginalized communities. New York, NY: Palgrave-Macmillan. 
Kemp, S. P. (2011). Recentring environment in social work practice: Necessity, opportunity, challenge. British Journal of Social Work, 41, 1198-1210. doi:10.1093/bjsw/bcr119

Lavelle, M., \& Coyle, M. (1992). Unequal protection: The racial divide in environmental law. National Law Journal, 15, S1-S12.

Lerner, S. (2010). Sacrifice zones: The front lines of toxic chemical exposure in the United States. Cambridge, MA: MIT Press.

Mary, N. L. (2008). Social work in a sustainable world. Chicago, IL: Lyceum Books, Inc.

McKinnon, J. (2008). Exploring the nexus between social work and the environment. Australian Social Work, 61, 256-268. doi:10.1080/03124070802178275

Medoff, P. (1994). Streets of hope: The fall and rise of an urban neighborhood. Boston, MA: South End Press.

Miller, S. E., Hayward, R. A., \& Shaw, T. V. (2012). Environmental shifts for social work: A principles approach. International Journal of Social Welfare, 21, 270-277. doi:10.1111/j.14682397.2011.00848.x

Minkler, M., Garcia, A. P., Williams, J., LoPresti, T., \& Lilly, J. (2010). Si’ se puede: Using participatory research to promote environmental justice in a Latino community in San Diego, California. Journal of Urban Health, 87, 796-812. doi:10.1007/s11524-010-9490-0

Minkler, M., \& Wallerstein, N. (2011). Community-based participatory research for health: From process to outcomes. San Francisco, CA: Jossey-Bass.

Mohai, P., \& Bryant, B. (1992). Race, poverty, and the environment. EPA Journal, 18, 6-8.

Mohai, P., Pellow, D., \& Roberts, J. T. (2009). Environmental justice. Annual Review of Environment and Resources, 34, 405-430. doi:10.1146/annurev-environ-082508-094348

Morello-Frosch, R., \& Jesdale, B. M. (2006). Separate and unequal: Residential segregation and estimated cancer risks associated with ambient air toxics in U.S. metropolitan areas. Environmental Health Perspectives, 114, 386-393. doi:10.1289/ehp.8500

NASW. (2008). Code of ethics. Washington, DC: National Association of Social Workers.

Parry, G., Van Cleemput, P., Peters, J., Moore, J., Walters, S., Thomas, K., \& Cooper, C. (2004). 
The health status of gypsies and travellers in England. Sheffield: The University of Sheffield School of Health and Related Research.

Pillai, V. K., \& Gupta, R. (2012). The greening of social work. Retrieved from http://www.cswe.org/CentersInitiatives/KAKI/50754/66942.aspx

Rogge, M. E. (1993). Social work, disenfranchised communities, and the natural environment: Field education opportunities. Journal of Social Work Education, 29, 111-120.

Sze, J. (2007). Noxious New York: The racial politics of urban health and environmental justice. Cambridge, MA: MIT Press.

United Nations. (2000). We can end poverty: Millenium development goals and beyond 2015. Retrieved from http://www.un.org/millenniumgoals/environ.shtml

Wallerstein, N. B., \& Duran, B. (2008). The theoretical, historical, and practice roots of community based participatory research. In M. Minkler \& N. Wallerstein (Eds.), Community based participatory research for health (pp. 27-52). San Francisco, CA: Jossey-Bass.

Whyte, W. F. (1991). Participatory action research. Thousand Oaks, CA: Sage. World Bank. (2015). Pollution management and environment health. Retrieved from http://www.worldbank.org/en/topic/environment/brief/pmeh

Zapf, M. K. (2009). Social work and the environment: Understanding people and place. Toronto, ON: Canadian Scholars' Press. 